\title{
Tangence
}

\section{Senses of Insecurity: Montreal Writers View their City}

\section{Michael Benazon}

Numéro 48, octobre 1995

Montréal et Vancouver : parcours urbains dans la littérature et le cinéma

URI : https://id.erudit.org/iderudit/025865ar

DOI : https://doi.org/10.7202/025865ar

Aller au sommaire du numéro

Éditeur(s)

Tangence

ISSN

0226-9554 (imprimé)

1710-0305 (numérique)

Découvrir la revue

Citer cet article

Benazon, M. (1995). Senses of Insecurity: Montreal Writers View their City.

Tangence, (48), 97-115. https://doi.org/10.7202/025865ar d'utilisation que vous pouvez consulter en ligne.

https://apropos.erudit.org/fr/usagers/politique-dutilisation/ 


\section{Senses of Insecurity : Montreal Writers View their City}

Michael Benazon

It is an axiom of contemporary critical thinking that an object has no reality per se. Meaning is attached to objects by what the viewer brings to them via upbringing, personal associations, ideology, national or religious mythology, and the like. Nowhere is this more obvious than in Montreal, a city whose aura has been determined by the varying attitudes of the people who live there.

Today the Montreal area is inhabited by two major linguistic groups: a French-speaking majority and an English-speaking minority. Within each group there are several ethnic or religious communities. In recent years, a number of writers from these smaller communities have emerged onto the literary scene. In so doing, they have extended the range and the depth of Montreal literature. Yet it was not so long ago that Montreal contained only three easily recognizable literary cultures: French, English, and Jewish. Each of these communities had its own distinct culture, and each produced its own literature. There was, however, very little social, cultural, or intellectual contact among them. The barriers were not only linguistic. There were cultural, religious, and class divisions, as well as the differences that usually exist between the newly arrived and the long established.

There are, of course, various ways of examining the three literatures, but this study will focus on the city imagery that tends to recur in the work of many Montreal writers. They are stimulated by the unusual geographical setting of the city, and also by the architectural variety which emerged partly from the differing social and cultural needs of the principal communities, partly from the different architectural traditions (principally British, French, and American) that they have inherited, and partly from the blatant rivalries and competitions between the French and English communities which initiated and continue to initiate spectacular or monumental buildings that assert a cultural or even a political presence in key areas of the city. 
98

By and large the writers, whatever their ethnic background, are fond of their city and eager to use it as a backdrop or symbolic setting in their fictional work. Yet much as they are charmed and fascinated by Montreal, the writers are also subject to feelings of insecurity. These feelings may be overtly expressed by fictional characters in the literature, but they are also consistently seen in the varied images of the city, which serve both as setting and as subtext. The following discussion will show how these feelings of insecurity manifest themselves in some of the French, English, and Jewish writers of Montreal. A summary of the use of city imagery in the works of French and English writers, with whom Canadian readers are generally quite familiar, will create the context for my more detailed examination of Montreal Jewish writers.

Modern French Montreal writers are as troubled by the presence of English and other people foreign to traditional Quebec society as were the earlier writers of the roman de terroir, but we find some nuances of difference. The city writers often have close personal experience with Quebec's cultural minorities and are capable of seeing their members as rounded individuals rather than as impersonal, hostile, or stereotypical étrangers. This may explain why the alien presence is as frequently conveyed in terms of city imagery as it is in terms of symbolic characters.

In Quartier Saint-Louis (1966), Robert de Roquebrune describes the gradual disintegration of upper Saint-Denis Street in the years immediately preceding World War I. While Roquebrune does not blame the English for what is happening, he nonetheless links the decline of the old French aristocracy to the tendency of these families to seek a more prestigious residence among the English of the West Island. Gabrielle Roy's novel, The Tin flute published in 1945, is largely set in Montreal's Saint-Henri quarter. The setting and mood are strikingly different; yet like Roquebrune, Roy avoids the hackneyed motif of the malevolent stranger. Here the disrupting element is the Second World War, which is associated with the armouries situated in English Westmount lying above Saint-Henri. But the lives of the people are also disrupted by the huge noisy trains which roll through the quarter, symbolizing perhaps the forces of industrialization and modern technology that menace traditional Quebec culture.

Writing in 1970, Jacques Ferron rails against our "petroleum civilization." In L'Amélanchier (1970, trans. The Juneberry Tree) he 
takes a dyspeptic view of the natural landmarks of the city. Ferron describes the St. Lawrence River as "nothing but an exposed sewer pipe" 1 and implies that the Edenic innocence of Quebec has been irrevocably tainted by a corruption emanating from the English west. Similarly, in his first two novels, Yves Beauchemin expressed concern about English domination of Quebec's economic and cultural life. This motif is accompanied by the imagery of a disintegrating city in Le Matou (1981). In his more recent Juliette Pomerleau (1989), Beauchemin joins the campaign to save and restore Montreal's old buildings under attack by a modern materialistic ethic that threatens to destroy the city's cultural heritage. A younger writer, André Carpentier (b. 1947), provides a final example of the elegiac melancholy that pervades French Montreal fiction. In his Rue Saint-Denis (1978), Carpentier laments the decline of Saint-Denis Street, which is becoming "more and more a kind of Crescent Street of the east," i.e. tainted by trendy English influences associated with "design and plastic." 2

These examples suffice to demonstrate that the French Montreal writers tend to be pessimistic about the ability of Quebec culture to survive the onslaught of North American culture and are concerned for the future. We can also say that the city imagery used in these works reveals a subtle though profound sense of insecurity.

The English-Canadian writers are greatly stimulated by Montreal, especially by the central downtown area. There is constant and often detailed reference to well-known buildings, streets, and public places to create a sense of place and a symbolic backdrop for the action. But over the years, we find a significant change in Montreal English fiction. Prior to the late 1950s, the characters exude a sense of confidence and security. Montreal is their city; they are at the centre of power, and they belong there. In some of the older writers, the presence of the French-speaking majority is ignored or barely mentioned. The sense of ethnocentric smugness that once prevailed in the English Montreal upper class is captured again and again in the satiric thrusts of Stephen Leacock's Arcadian Adventures with the Idle Rich (1914), a group of connected stories largely set on Sherbrooke Street.

1 Jacques Ferron, The Juneberry Tree [L Amélancbier], trans. Raymond Chamberlain, Montréal, Harvest, 1975, p. 117-18.

2 André Carpentier, Rue Saint-Denis, Montréal, Hurtubise, 1978, p. 38. 
100

Like Leacock, Morley Callaghan sensed the continuing selfsatisfaction of the all-powerful English upper class and set out to expose it in his ironic description of the setting of Joseph Carver's residence at the beginning of The Loved and the Lost (1951). The most interesting of his references is to the Château apartments on Sherbrooke Street, a structure that later appealed to Mavis Gallant and Mordecai Richler. The comparison of the Château to "a massive stone fortress" 3 is very apt, but there is no sense in Callaghan that the English of Montreal are in any way besieged in their mountain stronghold. That notion is suggested by Hugh MacLennan in The Watch that Ends the Night (1959), a novel published only eight years later: "[I]n those days [Montreal] was . . . an English garrison encysted in an overgrown French village. We belonged to the outer fringes of this garrison where the soldiering was done in the banks and trust houses. . ." The passage hints at the existence of a force without, that might one day besiege the citadel. MacLennan's imagery may perhaps be seen as the counterpart to those passages in Gabrielle Roy's The Tin flute which present the youthful Jean Lévesque as a man whose overriding ambition is to scale the walls of the Westmount fortress which overhangs Saint-Henri. Thus we can sense in MacLennan, as early as 1959, that all is not well in the château.

Mavis Gallant was also struck by the fortress-like quality of the Château apartments, which she describes as "a block of granite designed to look like a fortress." 5 But she also implies that the interior of the Château is decrepit and poorly maintained. It seems the château of the English establishment, like Edgar Allan Poe's House of Usher, is fatally cracked and awaits its doom. John Metcalf, on the other hand, uses architecture as a means of castigating the technology and materialism which have dehumanized modern humanity. David, the hero of Metcalf's Going Down Slow (1972), worries about "the Van Horne house with its graceful conservatory. All threatened with demolition." 6

In short, although the older English writers seem at first secure, confident, even smug about their place in the city, their use

3 Morley Callaghan, The Loved and the Lost, New York, Macmillan, 1951, p. 1.

4 Hugh MacLennan, The Watch that Ends the Night, New York, Scribner, 1959, p. 58 .

5 Mavis Gallant, "With a Capital T" 1977, Home Trutbs: Selected Canadian Stories, Toronto, Macmillan, 1982, p. 325.

6 John Metcalf, Going Down Slow, Toronto, McClelland \& Stewart, 1972, p. 81. 
of the fortress image betrays a nervousness about the future. They have finally begun to feel insecure in their mountain redoubt. The menace is not necessarily from Quebec nationalism, although MacLennan does express this concern. More typically, the writers see themselves confronted by the rising power of technology and modernism, which would dehumanize the individual and sacrifice the elegance of an older way of life to an expedient ethic based on greed. As the fortress decays from within, the violent forces from the outside, representing the destructive potential of modernism, threaten to seize control.

When the Jews of eastern Europe arrived in the 1880s, they were, perforce, obliged to fit into a city that was split along linguistic lines. Disembarking from the trains or ships that brought them to Montreal, they had only to walk a few hundred metres north and settle in on the streets that lay on either side of St. Lawrence Boulevard. Thus the Jewish ghetto was born. The new arrivals were able to communicate in Yiddish with Jews from other eastern European countries. However, their sponsors, the small uptown Jewish community, spoke English, and it was the English Protestant School Board, rather than the French Catholic School Board, that accepted the immigrant children to its schools. English therefore became their adopted language. This community developed a substantial literature both in Yiddish and in English roughly between 1930 and 1970.

The Jewish writers were at first somewhat indifferent to the long-standing concerns of their French and English colleagues with local history and politics-presumably because for most of this century, the Jewish community has been preoccupied with historical events taking place outside of Canada. It may also be true that the traditional rivalries between English and French Canadians were of little interest to the Jewish writers who for many years felt excluded by both sides. This situation changed in the 1960 s as the Jewish community began to see itself as part of the English-speaking minority in Quebec. One can point to the appearance of Herman Buller's One Man Alone (1963) and Leonard Cohen's Beautiful Losers (1966) as evidence of a newfound interest in local politics.

Over the decades, it is also possible to detect a change of setting taking place in Montreal Jewish literature. Older writers like A. M. Klein, Irving Layton, Shulamis Yelin, Abraham Ram and Ted 
102

Allan, all born between 1909 and 1916, tend to place their work in the former Jewish ghetto area along St. Lawrence Boulevard, where they spent their formative years. The next generation of Jewish writers-people like William Weintraub, Leonard Cohen, and C. J. Newman, born between 1926 and 1935-frequently set their work in the downtown or western areas of the city. The shift is particularly obvious in the work of Herman Buller (b. 1927) and Mordecai Richler (b. 1931): some of their early fictions are set in the ghetto area, although their later works take place in other parts of the city or the province.

Curiously, the Jewish novelists tend to show less interest in architecture than do their English or French confrères. While they frequently refer to streets and places, they reveal decidedly less concern for the aesthetic quality of the buildings, or for the city in general. The explanation may be that the Jews were not part of the early history of Montreal, and that until quite recently Jewish culture lacked an architectural tradition. Synagogues were important for what went on inside, not for the external or even the internal appearance of the building. Despite their relative indifference to French-English rivalries and to aesthetic concerns, Montreal's Jewish writers nonetheless frequently express apprehension about their place in Quebec society. These concerns appear as often in the poetry as they do in the prose.

The earliest of the Jewish writers to be discussed here is Oscar Ryan, born Oscar Rein in 1904. His novel Soon to Be Borm, published in 1980, is primarily concerned with the workers' struggle for social justice in Quebec, but Ryan is also troubled by the social and religious barriers that separate people and blind them to the realities of class struggle. Ryan's imagistic descriptions of Montreal evoke the wonder and sense of infinite possibility that often characterizes Jewish writing about Montreal. At times, however, the city imagery takes on an ominous tone as we see in the following evocation of Saint-Urbain Street as it was in 1909:

You are four years old and venture across the street from your father's house to the hospital of God, the Hôtel Dieu on St. Urbain Street. You touch the fortress face of the hospital wall and are frightened by its rough cold sooty stone so different from the warm russet bricks of your father's home. You touch the hostile rock and feel its clammy flesh. And as though in retaliation, an ugly horrible smelly bellicose monster of a bullyboy brat confronts you and pushes your face against the wall 
and you run back home and upstairs stumbling terrified, bleeding, wailing to your ma. ${ }^{7}$

For Jewish children, Montreal could be hostile and frightening, particularly in the period prior to World War II.

Irving Layton, born in 1912 , is a younger contemporary of Oscar Ryan. As a child living on Saint-Elisabeth Street, Layton was conscious of the gulf separating Jews from French Canadians. The sense that as children they had to fight for their place on the streets crops up several times in Layton's writing as in the following passage from Waiting for the Messiab (1985):

No more than five or six French-Canadian families lived on our street, side by side with the Jews though they might just as well have been living in Mozambique for all the intercourse Jews had with them. Most francophones lived in the area that stretched east of St. Denis. To the Jewish boys on our street, that was dangerous territory. I never found myself in it without feeling menaced. ${ }^{8}$

The association of a baleful racism with the ecclesiastical images of Catholic Montreal also recurs in Layton's poetry, as in "Gothic Landscape" (1951):

They stand like penitential Augustines

These trees; and in my Jewboy mind they are monks, Brown-robed, fearful after their long sleep in dungeons;

When I was a child one of them nearly caught me, But I escaped, tunnelling the snow to my mother's face;

But the cloister bells deafen me with insults, And sallowfaced acolytes inform The snowdrifts what to whisper against me; Autos-da-fé make red the immaculate sky; Come soon, O bright Tudor sun!

I do not like this monastic whiteness of winterIt is a Christ drained of all blood.?

In this poem, the narrator identifies the trees, the monks, the cloister bells, and the "whiteness of winter" with the historic Catholic persecution of the Jews. It should be noted, however,

7 Oscar Ryan, Soon to Be Born, Vancouver, New Star, 1980, p. 198-99.

8 Irving Layton, Waiting for the Messiab, Toronto, McClelland \& Stewart, 1985, p. $15-16$.

9 Irving Layton, Selected Poems, Toronto, McClelland \& Stewart, 1965, p. 8. 
104

that the poem conveys the atmosphere of a nightmare or a paranoic fantasy rather than an experience based on the reality of Jewish life in Montreal.

We find the same feeling of menace in the work of Abraham Boyarsky, a much younger writer, who was born in Germany in 1946 and immigrated to Canada around 1953. Memories of Europe colour his attitude to Montreal and to its people. In this passage from A Pyramid of Time (1978), the child protagonist superstitiously associates the fatal illness of his mother with the illuminated cross on Mount Royal :

I recall leaving school in the early afternoon twilight of winter and walking west along Duluth Street. The yellow cross atop Mount Royal loomed awesomely before me, suspended in the thickening dusk.

After Mother became ill, I took other routes home to avoid the Cross. But it did little good. They operated on her in the early spring. ${ }^{10}$

This kind of association is, however, quite rare in the younger generation of Jewish writers. They no longer seem to fear antisemitism or to suspect its presence. If the city imagery creates apprehension, it is for quite different reasons.

Mordecai Richler shows little interest in Montreal's great buildings and monuments. He is more attracted to cigar shops, pool rooms, bowling alleys, bars, cafés, restaurants-places where people meet. While the scene changes-St. Lawrence Boulevard of his youth giving way to Sherbrooke Street of his adult life - the nostalgic note continues to pervade his work. He is interested more in the mood or atmosphere, than in the physical description of the site. Characteristically, these descriptions are treated ironically or comically:

The Ritz had fallen on such times that it now admitted visiting hockey players to its gilt bedrooms-even the players from expansion teams. The Café de Paris, the Maritime Bar, would never be the same. ${ }^{11}$

10 Abraham Boyarsky, A Pyramid of Time, Erin, Ont., Procupine's Quill, 1978, p. 16-17.

11 Mordecai Richler, Josbua Then and Now, Toronto, McClelland \& Stewart, 1980 , p. 67. 
Though Leonard Cohen, too, has a flair for broad comedy, we feel that the images of the city in his work are fraught with implications of defeat, decadence, and death. In The Favourite game (1963), for example, he attacks the modern consciousness which has subverted traditional values:

A religious stink hovers above this city and we all breathe it. Work goes on at the Oratoire St. Joseph, the copper dome is raised. The Temple Emmanuel initiates a building fund. A religious stink composed of musty shrine and tabernacle smells, decayed wreaths and rotting bar-mitzvah tables. Boredom, money, vanity, guilt, packs the pews. ${ }^{12}$

Lawrence Breavman's late-romantic complaints are similar to the fulminations of John Metcalf's protagonists in Going Down Slow (1972) and General Ludd (1980): modern man is being dehumanized by the relentless push of technology, urbanization, and greed. Elsewhere in The Favourite game, Cohen uses Montreal buildings and monuments as a symbolic backdrop to illuminate character and theme, in a manner akin to that of John Metcalf. He also reveals an aesthetic sensibility rare among Montreal Jewish writers.

Like Leonard Cohen, C. J. Newman does not feel threatened by racism. Yet in Newman's 1965 novel We Always Take Care of our Own, the city images have a disquietening effect on Meyer Rabinovitch, the young, rather simple-minded protagonist. Driving into Westmount on a visit to wealthy relatives, Meyer's father praises success, family connection, and tradition. Meyer disagrees but keeps his thoughts to himself :

Already, however, everything conspired to prove his father wrong; for the homes of stone and brick and mock-Tudor panelling, trellised and vine-covered, set at eccentric angles to each other and to the city below, with gardens and terraced slopes and trees, spoke abundantly of tradition. Only it wasn't their tradition, neither his nor his father's; it never could be. . . . His father's traditions, his father's pieties, were not the ones that were honoured here. ${ }^{13}$

12 Leonard Cohen, The Favourite Game, London, Secker \& Warburg, 1963, p. 214.

13 C.J. Newman, We Always Take Care of our Own, Toronto, McClelland \& Stewart, 1965, p. 16. 
106

Meyer finds himself indifferent to Montreal's "enormous office blocks in the international bland style" just as he is unexcited by the older buildings:

The slum areas, however-Victoriaville and St. Henri, the harbour area and St. Dominque and Coloniale and Murray and Williams and Colbourne Streets-these were another matter. These caught him by the throat and shook him; the sight of these hovels, the dilapidated wooden and tin buildings, the eroded brick buildings, the close streets, the children who seemed to have been conceived, carried, born and forgotten in these streets, demonstrated to Meyer that the sick and starving in Africa and India . . . lie lightly upon our minds ... ${ }^{14}$

He is stirred not by the buildings but by what they symbolizethe enormous gulf between rich and poor. Where Gabrielle Roy's character Jean Lévesque stands in Saint-Henri Square looking enviously at Westmount looming above him, Meyer stands between the two quarters gazing at the city from his perspective in "the dull middle-class area" in which he grew up. Lacking the means or the energy to flee an ethic he can no longer accept, Meyer adopts a quixotic position: he will renounce his privileges and become a beggar.

Of the Montreal Jewish prose writers born after 1949, only Robert Majzels writes fully from within the Jewish experience. While such younger writers as Jerry Wexler, Donna Steinberg and Claire Rothman, often write from a Jewish perspective, their attitude towards the city is not very different from the attitude of their anglophone colleagues. Since they are no longer threatened by the traditional enemy of anti-semitism, they are no longer concerned with acceptance: the question is what to do with what has been gained. Perhaps it is significant that the heroine of Steinberg's novel I Lost It All in Montreal (1983) is a young Jewish woman who, having spent her entire life in the west island, ends up living alone in a cheap flat in Old Montreal, struggling to learn French: her plight is the same as that of any other Englishspeaking youth who wishes to survive in the new reality. She faces the same insecurity.

It is difficult to insist today on the existence of a separate Montreal Jewish literature. The younger Montreal Jewish anglo-

14 Newman, We Always Take Care of our Own, p. 43. 
phone writers, most of whom were born in this country, appear to be merging into Montreal English literature. On the other hand, the francophone Jewish writers, most of whom were born abroad (e.g. Naim Kattan, Monique Bosco, Régine Robin) are not ready for cultural assimilation, despite their close association with Montreal's French literary community. Simon Harel has argued that these Jewish writers are redefining, in their own terms, traditional Quebec literary values, valorizing the existence of a new multicultural francophone Quebec. ${ }^{15}$ If, as Harel implies, this is the wave of the future, then it is coming into being because there are other important writers from Quebec's cultural communities involved. The appearance of the francophone Jewish writers is a welcome addition to the Montreal literary scene, but so far there is not enough evidence to suggest that they are capable of rejuvenating the fading Montreal Jewish literary community.

\section{CHECKLIST}

\section{FRENCH PROSE WRITERS OF MONTREAL}

\section{Aquin, Hubert (1929-1977)}

Prochain épisode, Montréal, CLF, 1965.

Trou de mémoire, Montréal, CLF, 1968.

L'antipbonaire, Montréal, CLF, 1969,

Neige noire, Montréal, La Presse, 1974.

\section{Beauchemin, Yves (b. 1941)}

L'enfirouapé, Montréal, La Presse, 1974.

Le matou, Montréal, Québec/Amérique, 1981.

Juliette Pomerleau, Montréal, Québec/Amérique, 1989.

\section{Beaulieu, Victor-Lévy (b. 1945)}

Race de monde, Montréal, Jour, 1969.

Jos Connaissant, Montréal, VLB, 1970.

Un rêve québécois, Montréal, Jour, 1972.

Don Quichotte de la démanche, Montréal, L'Aurore, 1974.

Satan Belbumeur, Montréal, VLB, 1981.

Steven le bérault, Montréal, Stanké, 1985.

15 Simon Harel, "La parole orpheline de l'écrivain migrant," in Montréal imaginaire: ville et littérature, Pierre Nepveu et Gilles Marcotte eds., Montréal, Fides, 1992, p. 373-418. 
108

Bessette, Gérard (b. 1920)

La Bagarre, Montréal, CLF, 1958.

\section{Brossard, Nicole (b. 1943)}

French Kiss, étreinte exploration, Montréal, Jour, 1974.

Carpentier, André (b. 1947)

Rue Saint-Denis, Montréal, Hurtubise HMH, 1978.

Carrier, Rocb (b. 1937)

Il est par là, le soleil, Montréal, Jour, 1970.

Ferron, Jacques (b. 1912)

La charrette, Montréal, Hurtubise HMH, 1968.

L'Amélanchier, Montréal, Jour, 1970.

\section{Laferrière, Dany}

Comment faire l'amour avec un nègre sans se fatiguer, Montréal,

VLB, 1985.

de Roquebrune, Robert (1889-1978)

Testament de mon enfance, Paris, Plon, 1952.

Roy, Gabrielle (1909-1983)

Bonbeur d'occasion, Montréal, Pascal, 1945.

Alexandre Chenevert, Montréal, Beauchemin, 1954.

Thériault, Yves (1915-1983)

Aaron, Québec, ILQ, 1954.

Tremblay, Michel (b. 1942)

La grosse femme d'à côté est enceinte, Montréal, Leméac, 1978.

Thérèse et Pierrette à l'école des Saints-Anges, Montréal, Leméac, 1980.

La ducbesse et le roturier, Montréal, Leméac, 1982.

Des Nouvelles d'Édouard, Montréal, Leméac, 1984.

Le cour découvert, Montréal, Leméac, 1986.

Le premier quartier de la lune, Montréal, Leméac, 1989.

\section{ENGLISH PROSE WRITERS OF MONTREAL}

\section{Beresford-Howe, Constance (b. 1922)}

The Unreasoning Heart, New York, Dodd Mead, 1946.

The Invisible Gate, New York, Dodd Mead, 1949.

The Book of Eve, Toronto, Macmillan, 1973.

A Population of One, Toronto, Macmillan, 1977. 


\section{Callaghan, Morley (1903-1990)}

The Loved and the Lost, New York, Macmillan, 1951.

The Many Coloured Coat, New York, Coward-McCann, 1960.

Fennario, David (b. 1947)

Without a Parachute, Toronto, McClelland \& Stewart, 1974.

Fennario, David (b. 1947) and Daniel Adams

Blue Mondays, Verdun, Black Rock, 1984.

Gallant, Mavis (b. 1922)

My beart Is Broken, New York, Random, 1964.

Home Trutbs: Selected Canadian Stories, Toronto, Macmillan, 1981.

Across the Bridge, Toronto, McClelland \& Stewart, 1993.

Grabam, Gwetbalyn (1913-1965)

Earth and High Heaven, London, Cape, 1944.

Henderson, Keith (b. 1945)

The Restoration, Montreal, DC Books, 1987.

Hood, Hugb (b. 1928)

White Figure, White Ground, New York, Dutton, 1964. Around the Mountain, Toronto, Peter Martin, 1967.

A Game of Touch, Don Mills, Longman, 1970.

\section{Leacock, Stepben (1869-1944)}

Arcadian Adventures with the Idle Rich, London, John Lane, 1914.

\section{MacLennan, Hugb (1907-1990)}

Two Solitudes, New York, Duell Sloan, 1945.

The Watch that Ends the Night, New York, Scribners, 1959.

Return of the Sphinx, New York, Scribners, 1967.

Voices in Time, Toronto, Macmillan, 1980.

Metcalf, Jobn (b. 1938)

Going Down Slow, Toronto, McClelland \& Stewart, 1972.

General Ludd, Toronto, ECW, 1980.

Moore, Brian (b. 1921)

The Luck of Ginger Coffey, Boston, Little Brown, 1960.

\section{Sparling, Sharon}

The Nest Egg, Toronto, HarperCollins, 1991.

Trevanian

The Main, New York, Harcourt Brace, 1976. 


\section{JEWISH PROSE WRITERS OF MONTREAL}

A. ENGLish LANGUAGE:

\section{Allan, Norman}

Lies my Father Told Me, Toronto, Signet, 1975.

\section{Allan, Ted (b. 1916)}

"Cadieux Street Childhood," New Frontier, 1.12, April 1937, p. 10-11.

"Zaida," Canadian Jewish Congress Bulletin, Sept., 1949.

Love Is a Long Shot, Toronto, McClelland \& Stewart, 1984.

Don't you know anybody else? Toronto, McCleland \& Stewart, 1985.

\section{Appleby, Bertrum Horace (b. 1923)}

Montreal Adventure, Montreal, University Press, 1951.

\section{Ary, Solomon}

Four stories in Prism International, 18.2, Fall/Winter, 1979-80.

\section{Blicker, Seymour (b. 1940)}

Shmucks, Toronto, McClelland \& Stewart, 1972.

The Last Collection, Toronto, McClelland \& Stewart, 1976.

\section{Boyarsky, Abrabam (b. 1946)}

A Pyramid of Time, Erin, Ont., Porcupine's Quill, 1978.

Shreiber, Toronto, General, 1981.

Buller, Herman (b. 1927)

One Man Alone, Toronto, Canada National Book Club, 1963. Days of Rage, Montreal/Toronto, October Publications, 1974.

\section{Coben, Leonard (b. 1934)}

The Favourite Game, London, Secker \& Warburg, 1963. Beautiful Losers, Toronto, McClelland \& Stewart, 1966. Death of a Lady's Man, Toronto, McClelland \& Stewart, 1978.

\section{Klein, A. M. (1909-1972)}

The Second Scroll, New York, Knopf, 1951.

\section{Layton, Irving (b. 1912)}

The Swinging Flesh, Toronto, McClelland \& Stewart, 1961. Waiting for the Messiab, Toronto, McClelland \& Stewart, 1985.

Levine, Norman (b. 1923)

Canada Made Me, London, Putnam's, 1958

"The English Girl," 1964 (Montreal mon amour, Michael Benazon ed., Toronto, Deneau/Summerhill, 1989, p. 76-81). 
Ludwig, Jack (b. 1922)

A Woman of Her Age, Toronto, McClelland \& Stewart, 1973.

Majzels, Robert (b. 1950)

Hellman's Scrapbook, Dunvegan, Ont., Cormorant, 1992.

Nemiroff, Greta Hofmann (b. 1937)

"Chez Sergei," Room of One's Own, 6.3, 1981, p. 3-22.

"Seder," Matrix, no. 21, Fall 1985, p. 26-39.

Newman, C.J. (b. 1935)

We Always Take Care of our Own, Toronto, McClelland \& Stewart, 1965.

"Yenteh," New Canadian Writing, Toronto, Clarke, Irwin, 1969, p. 105-118.

Ram, Abrabam (b. c1915-20)

The Noise of Singing, Ottawa, Golden Dog, 1975.

Dark of Caves, Ottawa, Golden Dog, 1977.

Once in Woods, Ottawa, Golden Dog, 1982.

Ricbler, Mordecai (b. 1931)

Son of a Smaller Hero, London, Deutsch, 1955.

The Apprenticesbip of Duddy Kravitz, London, Deutsch, 1959.

The Street, Toronto, McClelland \& Stewart, 1969.

St. Urbain's Horseman, Toronto, McClelland \& Stewart, 1971.

Joshua Then and Now, Toronto, McClelland \& Stewart, 1980.

Solomon Gursky Was Here, Toronto, Penguin, 1989.

Roiter, Howard (b. 1939)

Here Comes Hymie!', Edmonton, Devonshire, 1990.

Rotbman, Claire (b. 1958)

Salad Days, Dunvegan Ont., Cormorant, 1990.

Ryan, Oscar (b. 1904)

Soon to Be Born, Vancouver, New Star, 1980.

\section{Sbubert, Hilda}

They Came from Kernitza, Montreal, Chateau, 1969.

\section{Steinberg, Donna (b. 1954)}

I Lost it All in Montreal, New York, Avon, 1983.

Stilman, Abram (b. 1903)

Mariette, Toronto, Burns \& MacEachern, 1961.

Levy, Montreal, Beauchemin, 1971. 
112

Weintraub, William (b. 1926)

Why Rock the Boat, Boston, Little, Brown, 1961.

The Underdogs, Toronto, McClelland \& Stewart, 1979.

Wexler, Jerry (b. 1950)

The Bequest, Montreal, Véhicule, 1984.

Yelin, Shulamis (b. 1913)

Shulamis: Stories from a Montreal Childbood, Montreal, Véhicule, 1983.

B. French Language:

Bosco, Monique (b. 1927)

La femme de Loth, Paris, Laffont, 1970.

Charles Léry, m.d., Montréal, Quinze, 1977.

Kattan, Naim (b. 1928)

The Neighbour and Other Stories, Trans. Judith Madley and

Patricia Claxton,. Toronto, McClelland \& Stewart, 1982.

La fiancée promise, Montréal, Hurtubise HMH, 1983.

Robin, Régine (b. 1939)

La Québécoite, Montréal, Québec/Amérique, 1983.

\section{CRITICISM}

Agrs, Arnold, "Canadian Jewish Writin," Chronicle Review, Dec. 1972, p. 15-19.

ANctil, Pierre, "Les Écrivains juifs de Montréal," Juifs et réalités juives au Québec, Pierre Anctil and Gary Caldwell ed., Quebec, IQRC, 1984, p. 195-252.

AkNolD, Janice, "David Rome on Canadian Jewish Literature," Chronicle Rreview, Nov. 1975, p. 19-21.

Butovsky, Mervin et al., "Thoughts on Our Culture," Vieupoints, 11.1, Summer 1980, p. 22-27.

Afterword to Y. Zipper's The Far side of the River, Oakville, Mosaic, 1985.

Chassay, Jean-François, Bibliographie descriptive du roman montréalais, Montreal, Université de Montréal, 1991.

E1)Fl, Leon, "Marginal Keri and Textual Chetiv," The A. M. Klein Symposium, Seymour Mayne ed., Ottawa, University of Ottawa Press, 1975. 
GERSON, Carole, "Some Patterns of Exile in Jewish Writing of the Commonwealth," Ariel, no. 13.4, 1982, p. 103-14.

GODARD, Barbara, "The City of Montreal in the English and French Canadian Novel 1945-65," M. A. Diss., Université de Montréal, 1967.

-, "The Geography of Separatism," Laurentian University Review, no. 9.1, Nov. 1976, p. 33-50.

Greenstein, Michael, "Beyond the Ghetto and the Garrison: Jewish Canadian Boundaries," Mosaic, no. 14.2, Spring 1981, p. 121-30.

, Third Solitudes: Tradition and Discontinuity in JewishCanadian Literature, Montreal, McGill-Queen's, 1989.

Harel, Simon, "La Parole orpheline de l'écrivain migrant," Montréal imaginaire: ville et littérature, Pierre Nepveu et Gilles Marcotte eds, Montreal, Fides, 1992, p. 373-418.

Journal of Canadian studies, A. M. Klein's Montreal, 19.2, Summer 1984.

KatTan, Naim, "Le Visage de Montréal vu par des romanciers de langue anglaise," Présence de la critique: Critique et littérature contemporaines au Canada français, Gilles Marcotte ed, Montreal, HMH, 1966, p. 187-94.

, "Montreal and French-Canadian Culture: What They Mean to English-Canadian Novelists," Tamarack Review, 40, Summer 1966, p. 40-53.

- "Deux romanciers canadiens-anglais et Montréal," Culture populaire et littératures au Québec, René Bouchard ed., Saratoga, Anma Libri, 19, 1980, p. 257-63.

LAPPIN, Ben, "The Receding World of Abraham Klein," Viewpoints, 2.4, Spring 1981, p. 16-29.

Mandel, Eli, "Ethnic Voice in Canadian Literature," Anotber Time, Erin Ont., Porcepic, 1977, p. 91-102.

Melançon, Benoît, "La Littérature montréalaise des communautés culturelles: prolégomènes et bibliographie," Montréal, Montréal imaginaire, Université de Montréal, 1990.

_- "La Littérature montréalaise et les ghettos," Voix $\varepsilon$ Images, 16.3, Spring 1991, p. 482-91. 
114

NADEL, Ira, Jewish Writers of North America, Detroit, Gale, 1981. , "The Absent Prophet in Canadian Jewish Fiction," English Quarterly, 5, Spring-Summer 1972, p. 83-92.

NEPVEu, Pierre, "Les Juifs à Montréal: le tiers inclus?," Montréal, L'Invention juive, Montreal, Montréal imaginaire, Université de Montréal, 1991, p. 73-86.

Robin, Régine, "Entre l'enfermement communautaire et le désastre individualiste: une voix pour l'écriture juive," Montréal, L'Invention juive, Montreal, Montréal imaginaire, Université de Montréal, 1991, p. 5-24.

Robinson, Ira, Pierre ANctil \& Mervin Butovsky, An Everyday Miracle: Yiddish Culture in Montreal, Montreal, Véhicule, 1990.

Rome, David, "Literature of Jewish Canadiana," Jewish Book Annual, 18, 1960-61, p. 44-53.

__., "Jews in Canadian Literature, a Bibliography," 2 vols., Montreal, Canadian Jewish Congress \& Jewish Public Library, 1964.

- - Recent Canadian Jewish authors and La Langue française, Montreal, Jewish Public Library, 1970.

- , "The Canadian Poets and the Immigrants," JIAS News, 20.1, March 1973, p. 3.

Rome, David, Judith NeFsky \& Paule OBERmeIER, Les Juifs du Québec, bibliographie rétrospective annotée, Quebec, IQRC, 1981, p. $190-217$.

— "Jews in Anglophone Quebec," The English of Quebec: From Majority to Minority Status, Gary Caldwell and E. Waddell eds, Quebec, IQRC, 1982.

SARKONAK, Ralph, "The Text as Crossroads," Canadian Literature, 112, Spring 1987, p. 100-02.

Shek, Ben-Z, "The Jew in the French-Canadian Novel," Viewpoints, 4.4, Winter 1969, p. 29-35.

—_, French-Canadian and Québécois Novels, Toronto, Oxford, 1991.

Simon, Sherry, "The Language of Difference: Minority Writers in Quebec," Canadian Literature Supp. no. 1, May 1987, p. 119-28. 
__ , Entre les langues: l'écriture juive contemporaine à Montréal," Montréal, L'Invention juive, Montreal, Montréal imaginaire, Université de Montréal, 1991, p. 87-102.

SIroIs, Antoine, Montréal dans le roman canadien, Montréal, Didier, 1968.

_- "Conquête horizontale et verticale de la ville," Canadian Literature, 72, Spring 1977, p. 45-8.

STRATFORD, Philip, "Romanciers et nouvellistes anglophones du Québec: 1970-80," Protée, 10.2, Summer 1982, p. 1-14.

WADDINGTON, Miriam, "Introduction" to Canadian Jewish Short Stories, Miriam Waddington ed., Toronto, OUP, 1990.

WOLFE, Morris and Gerri SinclarR, "Introduction" to The Spice Box: An Antbology of Jewish Canadian Writing, Toronto, Lester \& Orpen Dennys, 1981. 